\title{
Article \\ Effect of Erythropoietin on the Expression of Murine Transferrin Receptor 2
}

\author{
Betty Berezovsky, Martin Báječný, Jana Frýdlová, Iuliia Gurieva, Daniel Wayne Rogalsky, Petr Přikryl (D, \\ Vít Pospíšil, Emanuel Nečas (D), Martin Vokurka and Jan Krijt *
}

Institute of Pathophysiology, First Faculty of Medicine, Charles University, U Nemocnice 5, 12853 Prague, Czech Republic; bettyberezovsky@gmail.com (B.B.); mbaje@lf1.cuni.cz (M.B.); jana.frydlova@lf1.cuni.cz (J.F.); gurieva.jul@seznam.cz (I.G.); danielrogalsky12@gmail.com (D.W.R.); pprik@lf1.cuni.cz (P.P.); vitek_pos@hotmail.com (V.P.); necas@cesnet.cz (E.N.); mvoku@lf1.cuni.cz (M.V.)

* Correspondence: jkri@lf1.cuni.cz

Citation: Berezovsky, B.; Báječný, M.; Frýdlová, J.; Gurieva, I.; Rogalsky, D.W.; Přikryl, P.; Pospíšil, V.; Nečas, E.; Vokurka, M.; Krijt, J. Effect of Erythropoietin on the Expression of Murine Transferrin Receptor 2. Int. J. Mol. Sci. 2021, 22, 8209. https:// doi.org/10.3390/ijms22158209

Academic Editor: Paolo Arosio

Received: 3 June 2021

Accepted: 28 July 2021

Published: 30 July 2021

Publisher's Note: MDPI stays neutral with regard to jurisdictional claims in published maps and institutional affiliations.

Copyright: (C) 2021 by the authors. Licensee MDPI, Basel, Switzerland. This article is an open access article distributed under the terms and conditions of the Creative Commons Attribution (CC BY) license (https:/ / creativecommons.org/licenses/by/ $4.0 /)$.

\begin{abstract}
Erythropoietin (EPO) downregulates hepcidin expression to increase the availability of iron; the downregulation of hepcidin is mediated by erythroferrone (ERFE) secreted by erythroblasts. Erythroblasts also express transferrin receptor 2 (TFR2); however, the possible role of TFR2 in hepcidin downregulation is unclear. The purpose of the study was to correlate liver expression of hepcidin with the expression of ERFE and TFR2 in murine bone marrow and spleen at 4, 16, 24, 48, 72 and $96 \mathrm{~h}$ following administration of a single dose of EPO. Splenic Fam132b expression increased $4 \mathrm{~h}$ after EPO injection; liver hepcidin mRNA was decreased at $16 \mathrm{~h}$. In the spleen, expression of TFR2 and transferrin receptor (TFR1) proteins increased by an order of magnitude at 48 and $72 \mathrm{~h}$ after EPO treatment. The EPO-induced increase in splenic TFR2 and TFR1 was associated with an increase in the number of Tfr2- and Tfr1-expressing erythroblasts. Plasma exosomes prepared from EPO-treated mice displayed increased amount of TFR1 protein; however, no exosomal TFR2 was detected. Overall, the results confirm the importance of ERFE in stress erythropoiesis, support the role of TFR2 in erythroid cell development, and highlight possible differences in the removal of TFR2 and TFR1 from erythroid cell membranes.
\end{abstract}

Keywords: hepcidin; erythroferrone; transferrin receptor; exosomes

\section{Introduction}

Iron is a central component of hemoglobin. Accordingly, functional erythropoiesis is critically dependent on adequate iron supply, as clearly illustrated by the pathophysiology of iron-deficiency anemia [1]. Developing erythroblast express high levels of transferrin receptor (TFR1) which mediates internalization of circulating diferric transferrin by receptor-mediated endocytosis to ensure adequate iron uptake for hemoglobin synthesis [2].

In addition to TFR1, erythroid cells also express transferrin receptor 2 (TFR2). TFR2 has lower affinity for circulating transferrin [3], and its role in iron acquisition remains unclear. Whereas mice deficient in TFR1 die in utero with severe iron deficiency [4], Tfr2-mutated mice display iron overload [5] due to increased iron absorption from the intestine. In contrast to the ubiquitously expressed transferrin receptor, TFR2 is mainly expressed in hepatocytes where it plays an important role in the regulation of iron absorption [5,6]. Although Tfr 2 mRNA is also found in erythroleukemic cell lines and in murine erythroblasts [3], global deletion of the Tfr2 gene in mice results only in a mild change of hematologic parameters $[7,8]$, strongly suggesting that the primary physiological function of TFR2 is the regulation of dietary iron absorption, rather than iron delivery to erythroid cells. Nevertheless, the potential role of TFR2 in erythropoiesis and its regulation has recently received more attention [9]; at present, the exact role of TFR2 in erythroid cells is still unclear and under active investigation [10-14]. 
Transferrin-bound iron is regarded as the major physiological source of iron for erythropoiesis, as documented by severe anemia in hypotransferrinemic mice [15]. During states of accelerated erythropoiesis, it is imperative to increase iron export from iron-storing macrophages into plasma in order to ensure adequate iron loading of circulating transferrin. To this purpose, accelerated erythropoiesis downregulates the synthesis of hepcidin, the systemic regulator of cellular iron export. Hepcidin is a small hepatocyte-derived peptide whose primary role is to block iron export from duodenal enterocytes by degradation and inhibition of ferroportin. It has been known for almost twenty years that accelerated erythropoiesis decreases hepcidin (Hamp) expression in mice [16-18]. The mechanism of this erythropoiesis-mediated decrease of Hamp expression was elucidated only in 2014 when it was demonstrated that, upon stimulation by erythropoietin, erythroblasts produce erythroferrone (ERFE), a secreted protein which upon its release into circulation downregulates hepatic hepcidin synthesis [19]. Although it was originally postulated that hepatocytes express a specific receptor or receptors for ERFE [19], it has later been demonstrated that ERFE acts by binding and inactivating BMP6 protein and the BPM6/BMP2 heterodimer [20-22]. Bone morphogenetic proteins (BMPs) are major physiological regulators of hepcidin expression [23]. The BMP2 and BMP6 proteins are synthesized and secreted by liver sinusoidal endothelial cells, and, upon interacting with the bone morphogenetic protein receptor complex, stimulate hepcidin synthesis. Inactivation of $B m p 6$ or Bmp2 genes in mice is known to dramatically decrease Hamp expression [24,25]; therefore, sequestration of the BMP6 and BMP2 by circulating proteins such as ERFE can be expected to decrease hepcidin synthesis.

Very interestingly, it has recently been reported that TFR2 is able to bind the BMP2 protein and to affect BMP2-dependent signaling during bone development [26]. Theoretically, in analogy with ERFE, increased synthesis of TFR2 could thus contribute to hepcidin downregulation by binding of the BMP proteins. In the case of ERFE, it is known that its basal expression in erythroblasts is very low, but that it is rapidly induced following erythropoietin administration [19], with significant increase in ERFE (Fam132b) mRNA detectable already $4 \mathrm{~h}$ after EPO injection. No such information is yet available for TFR2, although it has been noted that repeated injections of erythropoietin result in marked increase in both Tfr2 mRNA and TFR2 protein in the spleen [27]. It is not known whether this increase represents a direct induction of TFR2 expression by EPO, or whether it is caused by EPO-induced expansion of a particular population of erythroid precursors.

The TFR1 and TFR2 proteins are to a significant degree similar. The classical transferrin receptor is expressed at all stages of murine erythroblast development [28], but as the erythroblasts develop into reticulocytes, it is removed from the cell surface and circulates in plasma, where it can be measured for diagnostic purposes [29,30]. The sequence at which the human TFR1 protein is cleaved during receptor shedding is absent from TFR2; nevertheless, shedding of human TFR2 has been described in in vitro experiments [31]. If TFR2 is cleaved from the membrane in vivo, it could circulate in plasma similarly to ERFE; alternatively, plasma TFR2 could be synthesized and secreted as the soluble TFR2 $\beta$ isoform [8]. In the case of TFR1, the initial removal of the protein from reticulocyte membrane is mediated by exosomes [32], small secretory vesicles which are loaded with plasma membrane proteins and subsequently released from the cell. TFR 1 is one of the most abundant proteins found in plasma exosomes; it has not yet been reported whether TFR2 could be removed from erythrocyte precursors by the same mechanism. Overall, compared to TFR1, several aspects of in vivo biosynthesis and processing of TFR2 in erythroid cells are still unclear, including the mechanism of its induction by EPO, its removal from the cell membrane, and its potential presence in plasma.

The purpose of this study was to determine the time course of Tfr 2 mRNA induction in the bone marrow and spleen following a single dose of erythropoietin, and to correlate it with the time course of hepatic hepcidin downregulation. In addition, the content of Tfr1, Tfr2 and Erfe mRNA was determined in erythroblast populations obtained by flow cytometry sorting after EPO administration. The results indicate that ERFE and TFR2 display 
different mechanisms of erythropoietin-mediated induction: Whereas erythroferrone is very rapidly induced in the bone marrow and the spleen by a transcriptional mechanism, the marked increase of TFR2 protein in the spleen following erythropoietin administration is mainly dependent on the increase of the number of TFR2-expressing cells. Comparison of the time courses of erythroferrone and TFR2 induction with the time course of hepcidin downregulation suggests that the role of ERFE in hepcidin suppression is dominant, with marked TFR2 induction occurring only after hepcidin downregulation. As to the mechanism of TFR1 and TFR2 shedding from erythrocyte precursors, plasma exosomes isolated from EPO-treated mice displayed increased amounts of TFR1, whereas no exosomal TFR2 protein could be detected. These results confirm the important role of exosomes in TFR1 processing, and suggest that the removal of TFR2 from the membrane of erythroid cells probably occurs by an exosome-independent mechanism. Most importantly, the similar time course of EPO-induced expression of TFR1 and TFR2 in the spleen supports a role of TFR2 in erythropoiesis regulation.

\section{Results}

\subsection{EPO Administration Induces Splenic TFR2 Protein Content at 48 and $72 \mathrm{~h}$ Post Injection}

Administration of a single dose of EPO (200 U/mouse) resulted in the expected increase of red blood cell parameters, which reached statistical significance at $48 \mathrm{~h}$ post application and later (Table S1). With the exception of the $24 \mathrm{~h}$ interval, plasma iron content was not significantly changed by EPO treatment (Table S1). Hamp mRNA content started to decrease at $16 \mathrm{~h}$ post application, at $24 \mathrm{~h}$ the decrease was statistically significant (Figure 1). The decreased expression of hepcidin was associated with a decrease in BMP/SMAD signaling, as evident from the decrease in Id1 mRNA content (Figure 1). Both bone marrow and spleen Fam $132 b$ mRNA content were dramatically increased at $4 \mathrm{~h}$ after EPO administration (Figure 2a,b). Hamp mRNA as well as Fam132b mRNA content returned to control values 96 after injection (Figures 1 and 2).
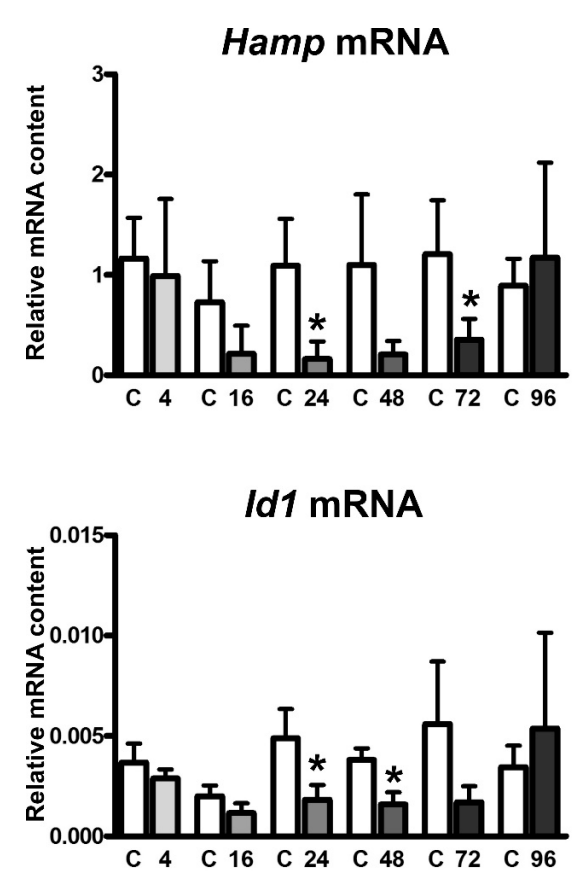

Figure 1. Single injection of EPO downregulates hepcidin expression at $16 \mathrm{~h}$ post injection. EPO was administered at $200 \mathrm{U} /$ mouse and the relative expression of liver Hamp and Id1 was determined at the indicated time points in groups of three control mice (C) and three EPO-treated mice. Target mRNA content is expressed relative to Actb expression, ${ }^{*}$ denotes statistical significance between EPO-treated group and the respective control group $(p<0.05)$. Values were obtained from two independent experiments. 

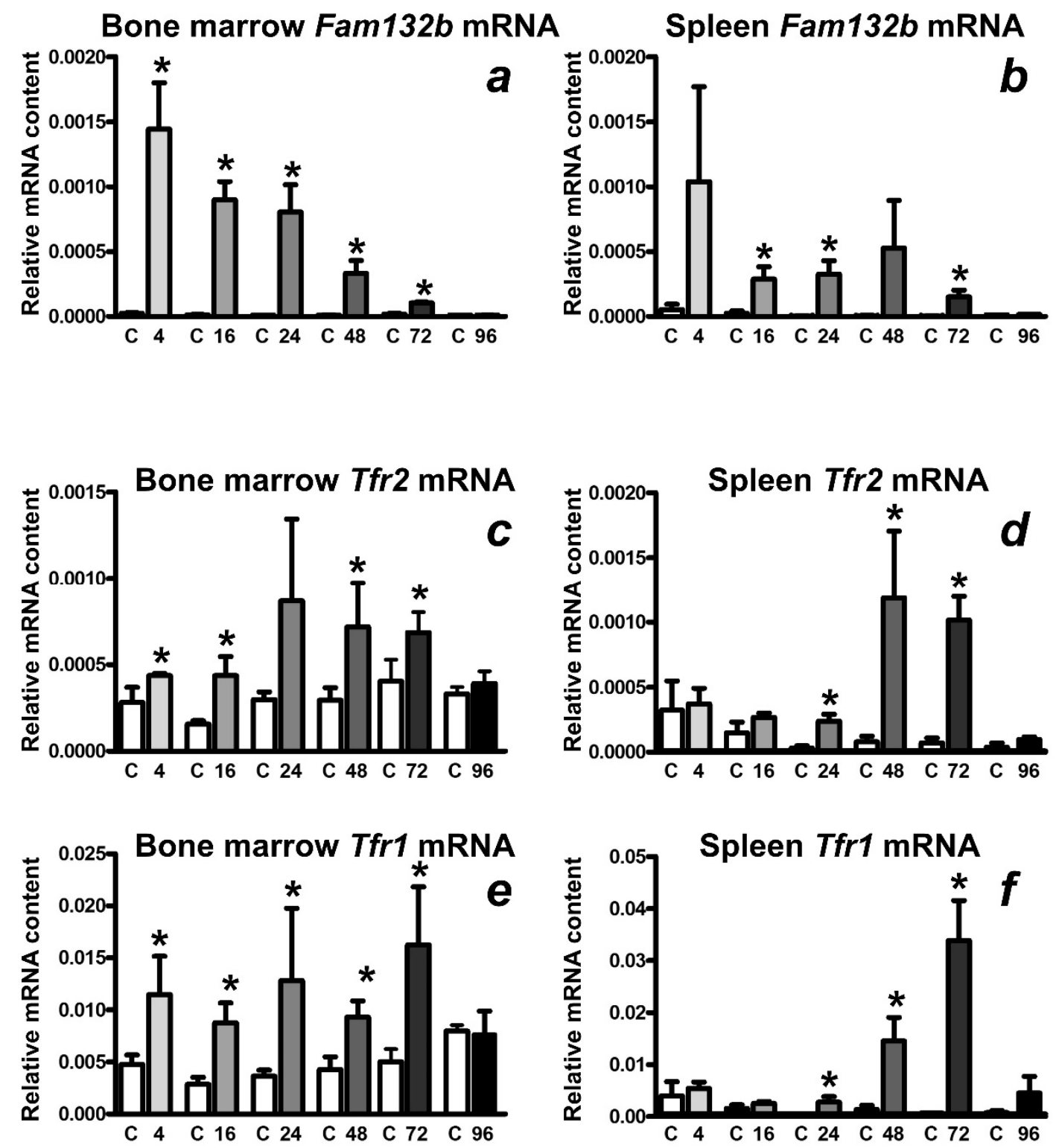

Figure 2. (a,b) Single injection of EPO rapidly upregulates Fam132b mRNA in the bone marrow and spleen. (c,d) Single injection of EPO upregulates splenic Tfr $2 \mathrm{mRNA}$ at $48 \mathrm{~h}$ and $72 \mathrm{~h}$ after injection. (e,f) Single injection of EPO upregulates splenic Tfr $1 \mathrm{mRNA}$ at $48 \mathrm{~h}$ and $72 \mathrm{~h}$ after injection. EPO was administered at $200 \mathrm{U} /$ mouse, mRNA content was determined at the indicated time points in groups of three control mice $(\mathrm{C})$ and three EPO-treated mice. Target mRNA content is expressed relative to $A c t b$ expression, ${ }^{*}$ denotes statistical significance between EPO-treated group and the respective control group $(p<0.05)$. Values were obtained from two independent experiments.

Tfr 2 mRNA in the bone marrow was increased at 4, 16, 48 and $72 \mathrm{~h}$ after EPO injection, maximal increase was approximately threefold (Figure 2c). Similar time course and magnitude was observed for marrow Tfr 1 mRNA induction (Figure 2e). In the spleen, no increase in Tfr 2 or Tfr 1 mRNA was observed at 4 and $16 \mathrm{~h}$; however, at $24 \mathrm{~h}$, both Tfr 2 and Tfr 1 mRNA started to increase, with maximum values, exceeding an order of magnitude, observed after 48 and $72 \mathrm{~h}$ respectively (Figure $2 \mathrm{~d}, \mathrm{f}$ ). Approximately similar time course, with peak values reached after 72 and $48 \mathrm{~h}$ post injection, was also observed for erythropoietin receptor (Epor) mRNA (Figure S1) and Cdc42bpa mRNA encoding the serine/threonine-protein kinase MRCK $\alpha$ (Figure S1), a recently identified TFR2 binding partner [14]. The splenic expression of Mcoln1 and $M f n 1$, two genes recently reported to be co-expressed together with TFR2 in human erythroblasts [11], was only slightly (less than 
two-fold) altered by EPO treatment (Figure S1), in contrast with the marked increase in splenic Tfr2 mRNA (Figure 2d).

The increase in splenic Fam132b, Tfr2 and Tfr1 mRNA content was closely mirrored by an increase of the respective proteins in splenic membrane fraction obtained by ultracentrifugation (Figure 3).
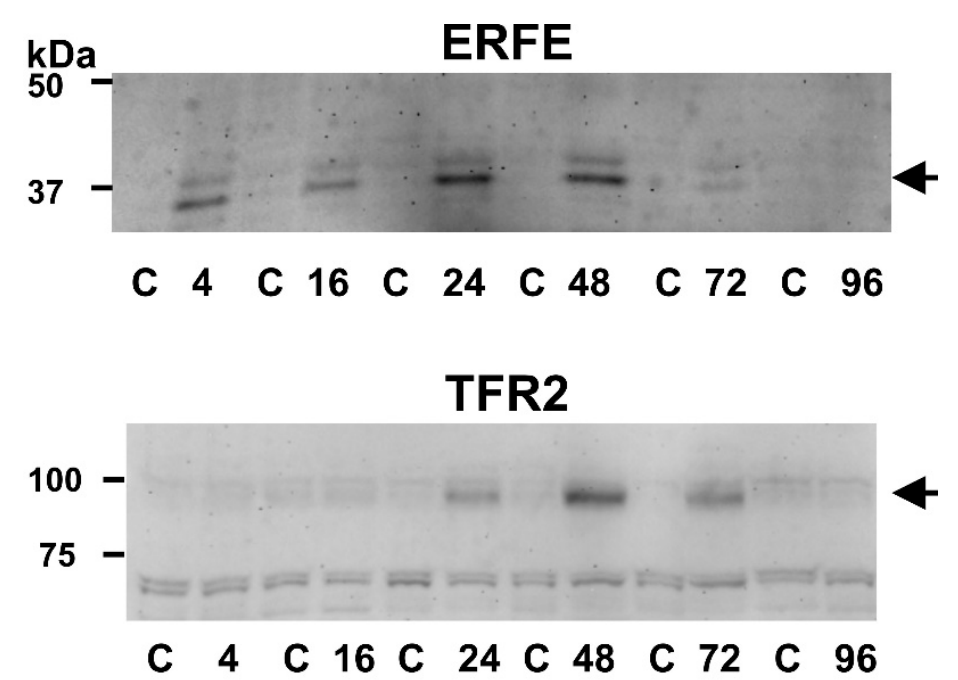

\section{TFR1}

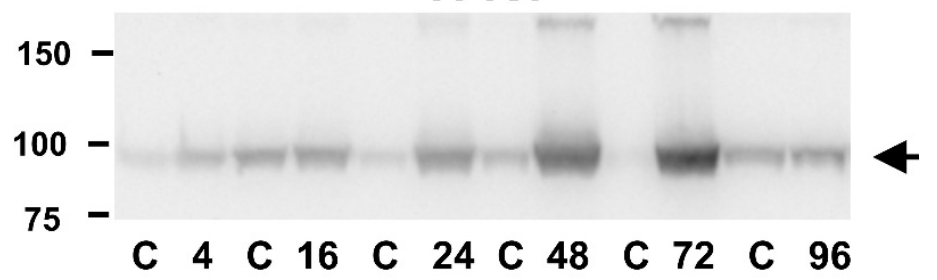

GAPDH

37

Figure 3. Single injection of EPO upregulates ERFE, TFR2 and TFR1 protein in the spleen. EPO was administered at $200 \mathrm{U} /$ mouse; target proteins were determined at the indicated time points $(4,16$, 24, 48, 72 and $96 \mathrm{~h}$ after EPO administration) in spleen membranes isolated from pairs of control (C) and EPO-treated animals. Sample loading is $35 \mu \mathrm{g}$ protein/well, GAPDH is used as loading control. Arrows denote the target protein bands.

\subsection{EPO Administration Increases the Number of Erythroid Precursors in the Spleen}

To determine the effect of EPO administration on the number of erythroid precursors in the spleen and bone marrow, cells were sorted at 24,48 and $96 \mathrm{~h}$ post injection according to the Ter119/CD44 pattern [28]. As can be seen in Figure 4, EPO treatment resulted in significant increase of the number of proerythroblasts and basophilic erythroblasts in the spleen at the $48 \mathrm{~h}$ interval. Since proerythroblasts are reported to display a higher level of Tfr2 expression in comparison with other erythroblast fractions [9], the marked increase in splenic TFR2 protein seen at $48 \mathrm{~h}$ post EPO injection (Figure 3) can be probably explained by the observed increase in proerythroblast numbers at this time point (Figure 4). 
Bone marrow

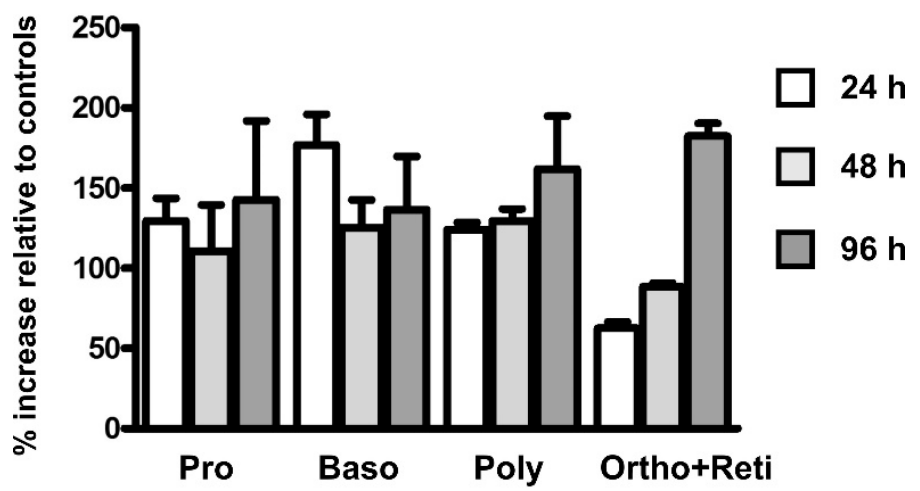

Spleen

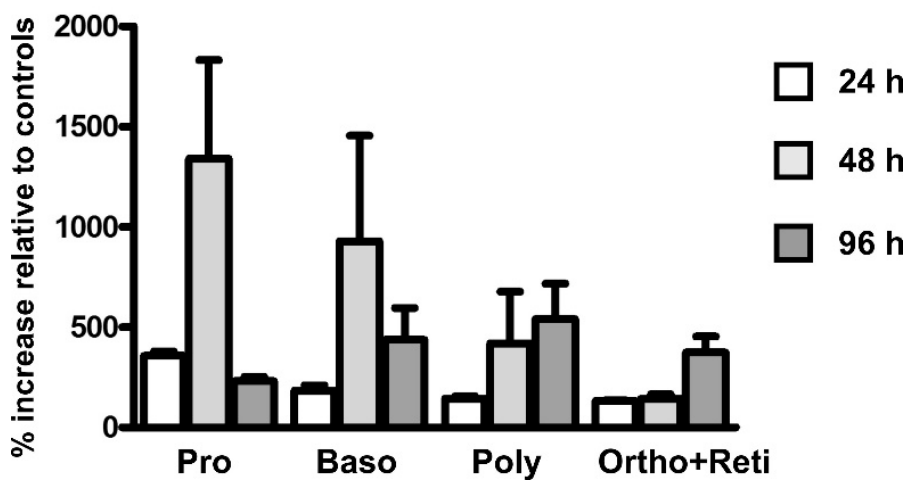

Figure 4. Single injection of EPO increases the number of proerythroblasts and basophilic erythroblasts in the spleen $48 \mathrm{~h}$ after treatment. EPO was administered at $200 \mathrm{U} /$ mouse; cell populations were obtained at indicated intervals by FACS sorting. Values represent the relative increase of cell populations in EPO-treated animals as compared to control animals (100\%). $n=3$, values were obtained from three independent experiments. Pro: Proerythroblasts; Baso: Basophilic erythroblasts; Poly: Polychromatophilic erythroblasts; Ortho + Reti: Orthochromatic erythroblasts and reticulocytes.

2.3. EPO Administration Increases the Content of Fam132b mRNA, but Not Tfr2 or Tfr1 mRNA, in Erythroid Precursors

To examine the effect of EPO treatment on the mRNA content of Tfr2 and Tfr1 in erythroid precursors, populations of proerythroblasts, basophilic erythroblasts and polychromatophilic erythroblasts were isolated by FACS sorting [28] from control and EPO treated bone marrow and spleen $48 \mathrm{~h}$ after EPO injection. As expected [19], EPO treatment resulted in dramatic upregulation of Fam132b mRNA in all three precursor populations. In contrast, Tfr2 and Tfr1 mRNA content was not significantly increased (Figure 5). As previously noted [9], the amount of Tfr 2 mRNA was markedly higher in proerythroblasts than in basophilic and polychromatophilic erythroblasts; however, we did not observe the reported [9] correlation between Tfr 2 and Epor expression, as, in contrast to Tfr 2 expression, Epor expression remained high in both basophilic erythroblast and polychromatophilic erythroblast (Figure 5). 
Bone marrow

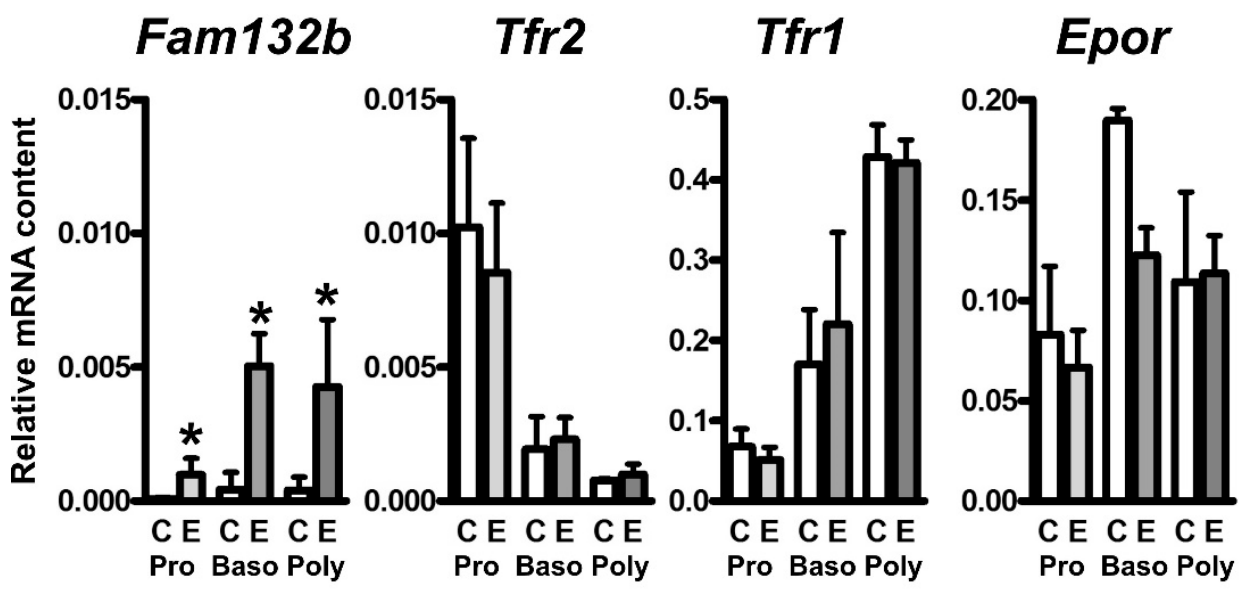

Spleen

Fam132b

Tfr2

Tfr1

Epor
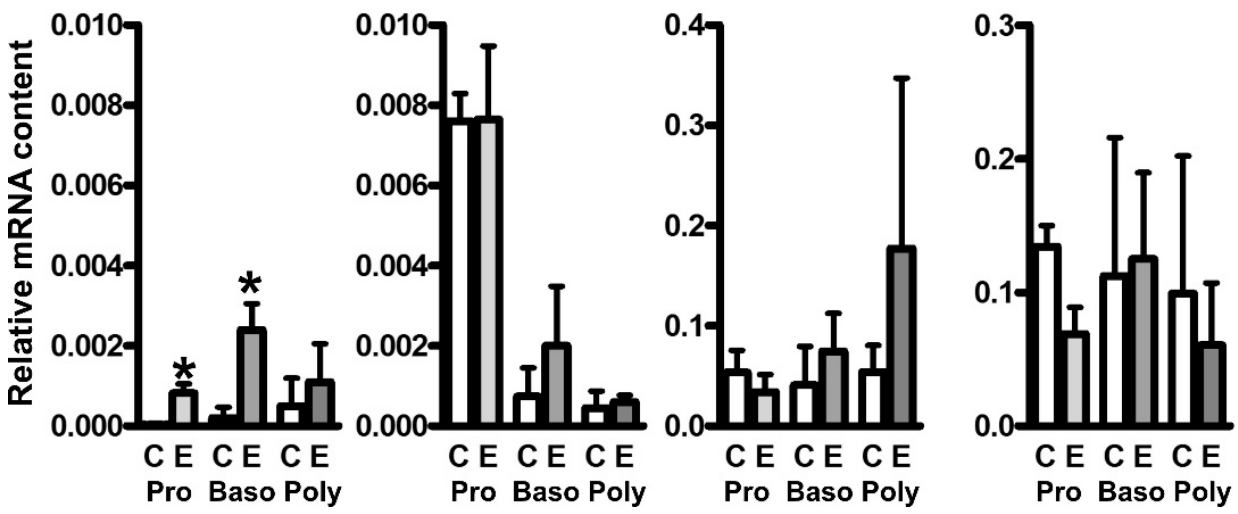

Figure 5. Single injection of EPO increases Fam132b expression in bone marrow and spleen erythroid precursors. EPO was administered at $200 \mathrm{U} /$ mouse; cell populations were obtained $48 \mathrm{~h}$ after treatment by FACS sorting. C: Expression in control populations, E: expression in EPO-treated populations. Pro: Proerythroblasts; Baso: Basophilic erythroblasts; Poly: Polychromatophilic erythroblasts. Target mRNA content is expressed relative to $A c t b$ expression, * denotes statistical significance between EPO-treated group and the respective control group $(p<0.05) . n=3$, values were obtained from three independent experiments.

\subsection{TFR2 Is Not Detected in Mouse Plasma Exosomes after EPO Administration}

It is very well established that during red blood cell maturation TFR1 is removed from the reticulocyte membrane and released into plasma [29,30]. In the case of TFR2, cleavage and release of the cleaved receptor has been described in vitro [31]. Since the Abcam ab80194 antibody is raised against the extracellular part of TFR2, it could theoretically detect circulating TFR2 in plasma. However, using albumin-depleted serum from Tfr2-/mice as negative control, no soluble TFR2 could be detected in EPO-treated mice (Figure S2), indicating that, in contrast to TFR1, the amount of plasma TFR2 is too low to be detected by immunoblotting.

Removal of TFR1 from reticulocyte membranes occurs through the secretion of exosomes, from whose surface the extracellular part of TFR1 is subsequently cleaved and shed [33]. Because EPO treatment increases both TFR1 and TFR2 protein synthesis, it was of interest to determine whether EPO administration will also increase the TFR1 and TFR2 protein content in plasma exosomes. As shown in Figure 6, exosomes isolated by ultracen- 
trifugation from plasma $72 \mathrm{~h}$ after EPO administration displayed increased TFR1-related signal compared to control exosomes. In contrast, no TFR2-related signal could be detected in exosomes from control or EPO-treated mice. These results suggest that the process of receptor removal from the membrane of erythroid cells might be different for TFR1 and TFR2.

TFR2

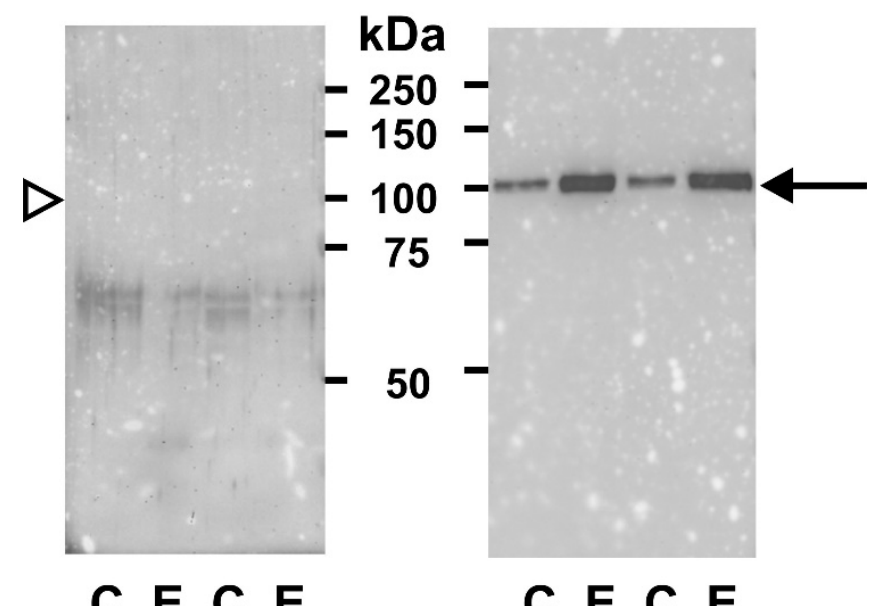

\section{GAPDH}

37

Figure 6. Single injection of EPO increases TFR1 protein content in plasma exosomes. Immunoblotting for TFR2 and TFR1 in plasma exosomes isolated from control (C) and EPO (E) treated mice. EPO was administered at $200 \mathrm{U} /$ mouse; mice were sacrificed $72 \mathrm{~h}$ after EPO injection. Arrow denotes the TFR1-specific band, arrowhead indicates the expected size of exosomal TFR2, which was not detected. The faint bands around $65 \mathrm{kDa}$ in the TFR2 panel are probably nonspecific. GAPDH is used as loading control.

\section{Discussion}

The crucial role of TFR1 in providing iron for erythropoiesis is established without any doubt [2]. In contrast, the exact function of TFR2 in erythroid cells is still unclear. Recently published data suggest that TFR2 could theoretically participate in bone morphogenetic protein binding [26] - a mechanism which closely resembles the recently proposed mode of action of ERFE [20-22]. Whereas the rapid induction of ERFE by EPO is well documented, much less is known about the time course of EPO-induced synthesis of TFR2. Therefore, the primary purpose of this study was to compare the expression of TFR2 with the expression of ERFE and TFR1 following a single dose of EPO. The results show a marked difference in the kinetics and mechanism of EPO-mediated induction between ERFE and both transferrin receptors.

ERFE has been originally discovered as a protein which mediates hepcidin downregulation during stress erythropoiesis [19]; accordingly, its expression rapidly increases following EPO injection. In contrast, the effect of EPO on the synthesis of Tfr 2 mRNA in bone marrow is much less pronounced. However, an intriguing pattern of Tfr 2 mRNA induction was observed in the spleen, where significant increase of Tfr 2 mRNA occurs at 48 and $72 \mathrm{~h}$ after EPO treatment (Figure 2d). Importantly, immunoblot analysis demonstrated that the observed increase in Tfr 2 mRNA is closely mirrored by an increase in the content of splenic TFR2 protein. Since spleen is the main site of EPO-induced stress erythropoiesis [34], 
the observed marked increase of splenic TFR2 protein suggests a possible role of TFR2 in mouse stress erythropoiesis.

The mechanism underlying the increase of TFR2 protein content in the spleen at $48 \mathrm{~h}$ and $72 \mathrm{~h}$ after EPO injection could theoretically involve direct EPO-mediated transcriptional increase of Tfr2 mRNA in individual cells, as is the case with ERFE [19], or it could reflect the EPO-induced increase of the number of TFR2-producing cells. In contrast to Fam132b mRNA, which was in accordance with previous studies [19] robustly induced in splenic proerythroblasts and basophilic erythroblasts, the effect of EPO on Tfr2 mRNA content in individual erythroid cell populations was not statistically significant (Figure 5). On the other hand, EPO significantly increased the number of proerythroblasts and basophilic erythroblasts in the spleen $48 \mathrm{~h}$ after treatment (Figure 4). Therefore, we conclude that the substantial increase in TFR2 protein observed in the spleen at $48 \mathrm{~h}$ and $72 \mathrm{~h}$ after EPO administration is caused by an increase in the number of TFR2-expressing cells, whereas the increase in ERFE protein reflects both the increase in ERFE-producing cells, as well as increased transcription of the Fam $132 b$ gene in individual cells. In accordance with previously published data [9], Tfr2 expression was markedly higher in proerythroblasts than in the later precursor populations; in contrast, Epor expression remained relatively high even in the late precursors (Figure 5) indicating that, in mice, the two genes are differently regulated during the later stages of erythroblast development.

Based on the recently reported TFR2/BMP2 interaction [26], the increased synthesis of TFR2 following EPO administration could theoretically contribute to the downregulation of hepcidin. However, comparison of the time course of hepcidin downregulation with the induction of ERFE and TFR2 proteins points to a major role of ERFE, rather than to a role of TFR2. In agreement with previously published data [19,35,36], Hamp expression decreases in less than $16 \mathrm{~h}$ following a single injection of EPO, whereas, as demonstrated in the present study, increased splenic TFR2 protein synthesis is seen only at $24 \mathrm{~h}$ and later. It is therefore evident that the early decrease in hepcidin expression must be related primarily to the induction od ERFE synthesis, or to the decrease of monoferric transferrin [35]. Nevertheless, since it has been reported that prolonged administration of EPO can downregulate hepcidin expression even in Fam132b-/- mice [37], the contribution of BMP-binding molecules other than ERFE to hepcidin downregulation can not be ruled out. In this respect, soluble TFR2 [31] or the beta isoform of TFR2 [8] represent interesting potential candidates.

In contrast to TFR2, whose role in erythroid cells is not yet completely clear, the function of TFR1 in erythropoiesis is established without any doubt [2]. Transferrin iron is regarded as the main physiological source of iron for hemoglobin synthesis, and TFR1 molecules are indispensable for efficient hemoglobinization. It is therefore interesting to note that the time course of splenic TFR1 and TFR2 induction following EPO administration is similar for both receptors, despite the known fact that the expression of both genes is regulated by different mechanisms. Tfr1 mRNA has five iron-responsive elements in its 3-untranslated region [38], which mediate the induction of TFR1 during states of iron deficiency; no such sequences are present in Tfr2 mRNA. Regardless, the time-response data following EPO administration are roughly similar for both receptors (Figures 2 and 3), supporting the concept that, in erythroid cells, the iron-responsive element-dependent control of Tfr1 expression is overridden [39] and erythroblast continue to take up iron despite high iron loading.

The approximately similar time course, as well as the approximately similar magnitude of splenic TFR1 and TFR2 induction following EPO treatment, indirectly support the hypothesis that TFR2 has an important role in erythroid development $[9,10]$. One such role could be iron acquisition from lysosomes [11]. Based on a similar expression pattern of TFR2, MCOLN1 and MFN2 genes, it has been suggested that TFR2 protein delivers iron from lysosomes to mitochondria, in cooperation with the mucolipin-1 and mitofusin-2 proteins [11]. However, the present study did not find significant correlation between splenic Tfr2 and Mcoln 1 or Mfn $2 \mathrm{mRNA}$, and thus does not provide additional experimental support for this proposed role of TFR2 in iron homeostasis. 
The TFR1 and TFR2 proteins are to a considerable extent similar, with analogous internalization motifs, domain organizations and disulfide bridges; both proteins exist as homodimers and it has even been reported that they can form heterodimers [40]. One substantial difference between them is the lack, in the TFR2 protein, of a cleavage sequence around arginine 100 at which human TFR1 is cleaved from the membrane by the protease PC7 [41]. Despite this discrepancy, the release of soluble TFR2 from an erythroleukemic cell line has been reported in in vitro experiments [31]. The removal of TFR1 from reticulocyte membranes is mediated by exosomes [32,33]; accordingly, plasma exosomes from EPOtreated mice were found to display increased amount of full-length TFR1 protein (Figure 6). At present, there is little information on the mechanism of removal of TFR2 from the membrane of erythroid cells. Due to the similarities between the two receptors, it was expected that plasma exosomes would contain, in addition to TFR1, detectable amount of TFR2. However, no TFR2-related signal was observed in plasma exosomes from control or EPO-treated mice. This failure to detect exosomal TFR2 could reflect the decrease of TFR2 protein content during later stages of erythroblast maturation, which has recently been reported in several cellular models of murine terminal erythroid differentiation [42], or it could be simply caused by low sensitivity of the antibody used. On the other hand, it could also point to a difference in the mechanism of removal of the two receptors from the membrane of murine erythroid cells in vivo. Since exosomal release of TFR2 protein has been reported in K562 cells [43,44], the role of exosomes in TFR2 processing remains a potential subject for further studies.

In conclusion, the presented study reports, at both mRNA and protein level, robust induction of TFR2 protein in the spleen at 48 and $72 \mathrm{~h}$ after a single injection of EPO. The underlying mechanism is probably the EPO-induced increase in TFR2-expressing cells in the spleen. The time course and magnitude of induction was approximately similar for both TFR2 and TFR1, despite the known absence of an IRE-IRP system in TFR2. Comparison of the time course of Hamp mRNA downregulation with the induction of Fam $132 b$ and Tfr 2 mRNA suggests that the effect on hepcidin synthesis in this experimental setting is mediated primarily by ERFE; nevertheless, contribution of TFR2 to hepcidin downregulation following prolonged administration of EPO can not be ruled out. Finally, the absence of detectable TFR2 in plasma exosomes suggests that each of the two transferrin receptors has a different mechanism for its removal from the cell membrane.

\section{Materials and Methods}

\subsection{Animals and Treatment}

All experiments were approved by the Ministry of Education of Czech Republic, protocol MSMT-11192/2020-2, dated April 28, 2020. Male C57BL/ 6 mice aged 8 weeks were treated by a single intraperitoneal injection of EPO (NeoRecormon Roche 2000, Roche Diagnostics GmbH, Penzberg, Germany) diluted in PBS at 200 U/mouse, control mice received PBS only. Animals were euthanized by ether anesthesia. Heparinized blood was obtained by retrobulbar puncture in ether anesthesia, red blood cells parameters were determined on Advia hematologic analyzer. Hematocrit values were determined by centrifugation in microtubes. Plasma iron was measured by a commercial kit (Fe Liquid, Erba-Lachema s.r.o., Brno, Czech Republic).

\subsection{RNA Analyses}

Liver and spleen tissue was stored in RNA Later; RNA was extracted using Qiagen RNEasy Plus Mini kit. For bone marrow RNA extraction, bone marrow from femurs was flushed directly into the Qiagen RLT Plus Buffer containing mercaptoethanol. Reverse transcription was performed by RevertAid kit (Thermo Fisher Scientific, Waltham, MA, USA). Real-time PCR analysis was run using BioRad SYBR Green Mix (Bio-Rad, Hercules, CA, USA) on a BioRad IQ5 cycler; beta actin (Actb) was used as a reference gene. Primer sequences are given in Table S2. 


\subsection{Immunoblotting}

Spleen ERFE, TFR2 and TFR1 proteins were determined in cell membranes obtained by ultracentrifugation. Spleen samples $(40-60 \mathrm{mg}$ ) were homogenized in $1 \mathrm{~mL}$ of $10 \mathrm{mM}$ Hepes buffer, $\mathrm{pH}$ 7.4, containing $250 \mathrm{mM}$ sucrose and protease inhibitor (Complete Mini, Roche, Sigma-Aldrich, Prague, Czech Republic). Homogenization was performed by $6 \mathrm{~mm}$ Ultra Turax homogenizer ( $3 \times 10 \mathrm{~s}$ at maximum speed). After $30 \mathrm{~min}$ on ice, homogenates were centrifuged for $15 \mathrm{~min}$ at $8000 \times g$ and the supernatant was subjected to ultracentrifugation at $100,000 \times g$ for one hour. Pellets were resuspended in $500 \mu \mathrm{L}$ of homogenization buffer and washed by another ultracentrifugation round; subsequently, washed pellets were resuspended in $75 \mu \mathrm{L}$ of $25 \mathrm{mM}$ ammonium bicarbonate containing $2 \%$ SDS. Proteins were separated under reducing conditions on $8 \%$ polyacrylamide gels, samples were heated at $85^{\circ} \mathrm{C}$ for $10 \mathrm{~min}$ prior to loading. Immunoblotting was performed on Invitrogen SureLock blotter using PVDF membranes. For the detection of full-length TFR2 protein in the spleen, the TFR21-A antibody from Alpha Diagnostics Intl. (San Antonio, TX, USA) raised against the intracellular part of TFR2 was used. Exosomes and serum were probed for TFR2 presence using Abcam ab80194 antibody raised against the extracellular part (AA 150-250) of human TFR2. The specificity of this antibody was verified on liver samples from Tfr2-/mice (Figure S3). Spleen TFR1 was detected using Abcam ab61134 antibody; exosome and serum TFR1 was detected by Abcam ab214039 antibody.

\subsection{Flow Cytometry and Cell Sorting}

Bone marrow cells were obtained from the long bones (femurs and tibias) by flushing the bone cavity with PBS supplemented with $1 \%$ bovine serum albumin through a hole in one end of the bone without clipping off the epiphyses. Spleen tissue was disrupted by a loosely fitting glass homogenizer. Single-cell suspension was obtained by repeated passage through a 25G needle and filtered through a $70 \mu \mathrm{m}$ nylon cell filter. Populations of erythrocyte precursors were identified by flow cytometry as based on the Ter119/CD44 pattern [28]. Gating strategy and experimental details are described in Figure S4. Cells were stained by fluorescently labeled antibodies for $20 \mathrm{~min}$ at $4{ }^{\circ} \mathrm{C}$ in the dark with antibodies listed in Table S3. RNA was isolated from the sorted populations using Qiagen RNEasy Micro kit (Qiagen N.V., Venlo, The Netherlands); 50,000 cells were sorted directly into $350 \mu \mathrm{L}$ of RLT buffer without mercaptoethanol, homogenized by vortexing for $60 \mathrm{~s}$ and after adding $375 \mu \mathrm{L}$ of $70 \%$ ethanol, processed according to the manufacturer instruction.

\subsection{Exosome Preparation}

Plasma exosomes were obtained by ultracentrifugation [32] from $1.5 \mathrm{~mL}$ of heparinized mouse plasma, the pellet was washed once with PBS. The final exosome pellet was resuspended in $30 \mu \mathrm{L}$ of $2 \%$ SDS in $25 \mathrm{mM}$ ammonium bicarbonate. Average yield of exosome protein was approximately $5 \mu \mathrm{g}$ of protein per $\mathrm{ml}$ of plasma.

\subsection{Statistical Analysis}

Values are graphed as mean $\pm S D$. Values between control groups and EPO-treated groups were compared by unpaired Students $t$-test. $p<0.05$ is regarded as significant.

Supplementary Materials: The following are available online at https://www.mdpi.com/article/10 .3390/ijms22158209/s1, Figure S1: Single injection of EPO upregulates Epor and Cdc42bpa mRNA in the spleen; Figure S2: Abcam ab80194 anti-TFR2 antibody does not detect TFR2 in serum; Figure S3: Validation of the anti-TFR2 ab80194 antibody; Figure S4: Gating strategy for FACS analyses; Table S1: Red blood cell parameters, spleen size and iron concentrations; Table S2: Primers used for PCR analysis, Table S3: Reagents used in immunophenotyping of hematopoietic cells.

Author Contributions: Conceptualization, J.K.; methodology, M.B., J.F., P.P., V.P., E.N.; investigation, B.B., M.B., J.F., I.G., D.W.R., J.K.; resources P.P., V.P., M.V.; writing-original draft preparation, J.K.; writing-review and editing, B.B., M.B., P.P., E.N.; supervision, E.N., M.V.; project administration, 
J.K.; funding acquisition, V.P., M.V. All authors have read and agreed to the published version of the manuscript.

Funding: This research was funded by UNIVERZITA KARLOVA V PRAZE, grant numbers PROGRES Q26 and SVV 260519. In addition, part of the material was funded from CZECH SCIENCE FOUNDATION, grant number GACR $20-22102 S$ to V.P.

Institutional Review Board Statement: The study was conducted according to the guidelines of the Declaration of Helsinki, and approved by the Ethics Committee of MINISTRY OF EDUCATION, CZECH REPUBLIC (protocol code MSMT-11192/2020-2).

Informed Consent Statement: Not applicable.

Data Availability Statement: The data presented in this study are available in the article and supplementary material. Further details, if needed, are available on request from the corresponding author.

Acknowledgments: The gift of Tfr2-/- liver samples from Marie-Paule Roth (Toulouse, France) and the gift of Tfr2-/- plasma samples from Antonella Roetto (Torino, Italy) is gratefully acknowledged. The authors thank Kamila Balušíková (Third Faculty of Medicine, Prague) and Jaroslav Truksa (Czech Academy of Sciences, Prague) for the gift of antibodies, and Luděk Šefc for the help with statistical analysis. Emanuel Nečas, Martin Vokurka, Jan Krijt and Jaroslav Truksa wish to gratefully acknowledge the long-lasting, helpful and stimulating theoretical support by Přemysl Poňka. His inspiring personality is sorely missed.

Conflicts of Interest: The authors declare no conflict of interest. The funders had no role in the design of the study; in the collection, analyses, or interpretation of data; in the writing of the manuscript, or in the decision to publish the results.

\section{References}

1. Camaschella, C. Iron deficiency. Blood 2019, 133, 30-39. [CrossRef]

2. Sheftel, A.D.; Mason, A.B.; Ponka, P. The long history of iron in the Universe and in health and disease. Biochim. Biophys. Acta 2012, 1820, 161-187. [CrossRef] [PubMed]

3. Kawabata, H.; Nakamaki, T.; Ikonomi, P.; Smith, R.D.; Germain, R.S.; Koeffler, H.P. Expression of transferrin receptor 2 in normal and neoplastic hematopoietic cells. Blood 2001, 98, 2714-2719. [CrossRef]

4. Levy, J.E.; Jin, O.; Fujiwara, Y.; Kuo, F.; Andrews, N.C. Transferrin receptor is necessary for development of erythrocytes and the nervous system. Nat. Genet. 1999, 21, 396-399. [CrossRef]

5. Fleming, R.E.; Ahmann, J.R.; Migas, M.C.; Waheed, A.; Koeffler, H.P.; Kawabata, H.; Britton, R.S.; Bacon, B.R.; Sly, W.S. Targeted mutagenesis of the murine transferrin receptor-2 gene produces hemochromatosis. Proc. Natl. Acad. Sci. USA 2002, 99, 10653-10658. [CrossRef] [PubMed]

6. Camaschella, C.; Roetto, A.; Calì, A.; De Gobbi, M.; Garozzo, G.; Carella, M.; Majorano, N.; Totaro, A.; Gasparini, P. The gene TFR2 is mutated in a new type of haemochromatosis mapping to 7q22. Nat. Genet. 2000, 25, 14-15. [CrossRef] [PubMed]

7. Forejtníková, H.; Vieillevoye, M.; Zermati, Y.; Lambert, M.; Pellegrino, R.M.; Guihard, S.; Gaudry, M.; Camaschella, C.; Lacombe, C.; Roetto, A.; et al. Transferrin receptor 2 is a component of the erythropoietin receptor complex and is required for efficient erythropoiesis. Blood 2010, 116, 5357-5367. [CrossRef] [PubMed]

8. Roetto, A.; Di Cunto, F.; Pellegrino, R.M.; Hirsch, E.; Azzolino, O.; Bondi, A.; Defilippi, I.; Carturan, S.; Miniscalco, B.; Riondato, F.; et al. Comparison of $3 \mathrm{Tfr} 2$-deficient murine models suggests distinct functions for Tfr2-alpha and Tfr2-beta isoforms in different tissues. Blood 2010, 115, 3382-3389. [CrossRef] [PubMed]

9. Nai, A.; Lidonnici, M.R.; Rausa, M.; Mandelli, G.; Pagani, A.; Silvestri, L.; Ferrari, G.; Camaschella, C. The second transferrin receptor regulates red blood cell production in mice. Blood 2015, 125, 1170-1179. [CrossRef] [PubMed]

10. Rishi, G.; Secondes, E.S.; Wallace, D.F.; Subramaniam, V.N. Hematopoietic deletion of transferrin receptor 2 in mice leads to a block in erythroid differentiation during iron-deficient anemia. Am. J. Hematol. 2016, 91, 812-818. [CrossRef]

11. Khalil, S.; Holy, M.; Grado, S.; Fleming, R.; Kurita, R.; Nakamura, Y.; Goldfarb, A. A specialized pathway for erythroid iron delivery through lysosomal trafficking of transferrin receptor 2. Blood Adv. 2017, 1, 1181-1194. [CrossRef]

12. Artuso, I.; Lidonnici, M.R.; Altamura, S.; Mandelli, G.; Pettinato, M.; Muckenthaler, M.U.; Silvestri, L.; Ferrari, G.; Camaschella, C.; Nai, A. Transferrin receptor 2 is a potential novel therapeutic target for $\beta$-thalassemia: Evidence from a murine model. Blood 2018, 132, 2286-2297. [CrossRef]

13. Wortham, A.M.; Goldman, D.C.; Chen, J.; Fleming, W.H.; Zhang, A.S.; Enns, C.A. Extrahepatic deficiency of transferrin receptor 2 is associated with increased erythropoiesis independent of iron overload. J. Biol. Chem. 2020, 295, 3906-3917. [CrossRef]

14. Richard, C.; Viret, S.; Cantero Aguilar, L.; Lefevre, C.; Leduc, M.; Faouzi, E.H.; Azar, N.; Lavazec, C.; Mayeux, P.; Verdier, F. Myotonic dystrophy kinase-related CDC42-binding kinase $\alpha$, a new transferrin receptor type 2-binding partner, is a regulator of erythropoiesis. Am. J. Hematol. 2021, 96, 480-492. [CrossRef] [PubMed] 
15. Trenor, C.C.; Campagna, D.R.; Sellers, V.M.; Andrews, N.C.; Fleming, M.D. The molecular defect in hypotransferrinemic mice. Blood 2000, 96, 1113-1118. [CrossRef]

16. Nicolas, G.; Viatte, L.; Bennoun, M.; Beaumont, C.; Kahn, A.; Vaulont, S. Hepcidin, a new iron regulatory peptide. Blood Cells Mol. Dis. 2002, 29, 327-335. [CrossRef] [PubMed]

17. Vokurka, M.; Krijt, J.; Šulc, K.; Nečas, E. Hepcidin mRNA levels in mouse liver respond to inhibition of erythropoiesis. Physiol. Res. 2006, 55, 667-674.

18. Pak, M.; Lopez, M.A.; Gabayan, V.; Ganz, T.; Rivera, S. Suppression of hepcidin during anemia requires erythropoietic activity. Blood 2006, 108, 3730-3735. [CrossRef]

19. Kautz, L.; Jung, G.; Valore, E.V.; Rivella, S.; Nemeth, E.; Ganz, T. Identification of erythroferrone as an erythroid regulator of iron metabolism. Nat. Genet. 2014, 46, 678-684. [CrossRef] [PubMed]

20. Arezes, J.; Foy, N.; McHugh, K.; Sawant, A.; Quinkert, D.; Terraube, V.; Brinth, A.; Tam, M.; LaVallie, E.R.; Taylor, S.; et al. Erythroferrone inhibits the induction of hepcidin by BMP6. Blood 2018, 132, 1473-1477. [CrossRef] [PubMed]

21. Arezes, J.; Foy, N.; McHugh, K.; Quinkert, D.; Benard, S.; Sawant, A.; Frost, J.N.; Armitage, A.E.; Pasricha, S.R.; Lim, P.J.; et al. Antibodies against the erythroferrone $\mathrm{N}$-terminal domain prevent hepcidin suppression and ameliorate murine thalassemia. Blood 2020, 135, 547-557. [CrossRef] [PubMed]

22. Wang, C.Y.; Xu, Y.; Traeger, L.; Dogan, D.Y.; Xiao, X.; Steinbicker, A.U.; Babitt, J.L. Erythroferrone lowers hepcidin by sequestering BMP2 / 6 heterodimer from binding to the BMP type I receptor ALK3. Blood 2020, 135, 453-456. [CrossRef]

23. Babitt, J.L.; Huang, F.W.; Wrighting, D.M.; Xia, Y.; Sidis, Y.; Samad, T.A.; Campagna, J.A.; Chung, R.T.; Schneyer, A.L.; Woolf, C.J.; et al. Bone morphogenetic protein signaling by hemojuvelin regulates hepcidin expression. Nat. Genet. 2006, 38, 531-539. [CrossRef]

24. Meynard, D.; Kautz, L.; Darnaud, V.; Canonne-Hergaux, F.; Coppin, H.; Roth, M.P. Lack of the bone morphogenetic protein BMP6 induces massive iron overload. Nat. Genet. 2009, 41, 478-481. [CrossRef]

25. Canali, S.; Wang, C.Y.; Zumbrennen-Bullough, K.B.; Bayer, A.; Babitt, J.L. Bone morphogenetic protein 2 controls iron homeostasis in mice independent of Bmp6. Am. J. Hematol. 2017, 92, 1204-1213. [CrossRef] [PubMed]

26. Rauner, M.; Baschant, U.; Roetto, A.; Pellegrino, R.M.; Rother, S.; Salbach-Hirsch, J.; Weidner, H.; Hintze, V.; Campbell, G.; Petzold, A.; et al. Transferrin receptor 2 controls bone mass and pathological bone formation via BMP and Wnt signaling. Nat. Metab. 2019, 1, 111-124. [CrossRef] [PubMed]

27. Frýdlová, J.; Rogalsky, D.W.; Truksa, J.; Nečas, E.; Vokurka, M.; Krijt, J. Effect of stimulated erythropoiesis on liver SMAD signaling pathway in iron-overloaded and iron-deficient mice. PLoS ONE 2019, 14, e0215028. [CrossRef]

28. Chen, K.; Liu, J.; Heck, S.; Chasis, J.A.; An, X.; Mohandas, N. Resolving the distinct stages in erythroid differentiation based on dynamic changes in membrane protein expression during erythropoiesis. Proc. Natl. Acad. Sci. USA 2009, 106, 17413-17418. [CrossRef]

29. Kohgo, Y.; Niitsu, Y.; Kondo, H.; Kato, J.; Tsushima, N.; Sasaki, K.; Hirayama, M.; Numata, T.; Nishisato, T.; Urushizaki, I. Serum transferrin receptor as a new index of erythropoiesis. Blood 1987, 70, 1955-1958. [CrossRef]

30. Cook, J.D.; Skikne, B.S.; Baynes, R.D. Serum transferrin receptor. Annu. Rev. Med. 1993, 44, 63-74. [CrossRef] [PubMed]

31. Pagani, A.; Vieillevoye, M.; Nai, A.; Rausa, M.; Ladli, M.; Lacombe, C.; Mayeux, P.; Verdier, F.; Camaschella, C.; Silvestri, L. Regulation of cell surface transferrin receptor-2 by iron-dependent cleavage and release of a soluble form. Haematologica 2015, 100, 458-465. [CrossRef]

32. Johnstone, R.M.; Adam, M.; Hammond, J.R.; Orr, L.; Turbide, C. Vesicle formation during reticulocyte maturation. Association of plasma membrane activities with released vesicles (exosomes). J. Biol. Chem. 1987, 262, 9412-9420. [CrossRef]

33. Johnstone, R.M. Cleavage of the transferrin receptor by human granulocytes: Preferential proteolysis of the exosome-bound TFR. J. Cell Physiol. 1996, 168, 333-345. [CrossRef]

34. Paulson, R.F.; Shi, L.; Wu, D.C. Stress erythropoiesis: New signals and new stress progenitor cells. Curr. Opin. Hematol. 2011, 18, 139-145. [CrossRef] [PubMed]

35. Mirciov, C.S.G.; Wilkins, S.J.; Hung, G.C.C.; Helman, S.L.; Anderson, G.J.; Frazer, D.M. Circulating iron levels influence the regulation of hepcidin following stimulated erythropoiesis. Haematologica 2018, 103, 1616-1626. [CrossRef] [PubMed]

36. Krijt, J.; Jonášová, A.; Neuwirtová, R.; Nečas, E. Effect of erythropoietin on hepcidin expression in hemojuvelin-mutant mice. Blood Cells Mol. Dis. 2010, 44, 257-261. [CrossRef] [PubMed]

37. Coffey, R.; Sardo, U.; Kautz, L.; Gabayan, V.; Nemeth, E.; Ganz, T. Erythroferrone is not required for the glucoregulatory and hematologic effects of chronic erythropoietin treatment in mice. Physiol. Rep. 2018, 6, e13890. [CrossRef]

38. Casey, J.L.; Hentze, M.W.; Koeller, D.M.; Caughman, S.W.; Rouault, T.A.; Klausner, R.D.; Harford, J.B. Iron-responsive elements: Regulatory RNA sequences that control mRNA levels and translation. Science 1988, 240, 924-928. [CrossRef]

39. Lok, C.N.; Ponka, P. Identification of an erythroid active element in the transferrin receptor gene. J. Biol. Chem. 2000, 275, 24185-24190. [CrossRef]

40. Vogt, T.M.; Blackwell, A.D.; Giannetti, A.M.; Bjorkman, P.J.; Enns, C.A. Heterotypic interactions between transferrin receptor and transferrin receptor 2. Blood 2003, 101, 2008-2014. [CrossRef]

41. Guillemot, J.; Canuel, M.; Essalmani, R.; Prat, A.; Seidah, N.G. Implication of the proprotein convertases in iron homeostasis: Proprotein convertase 7 sheds human transferrin receptor 1 and furin activates hepcidin. Hepatology 2013, 57, 2514-2524. [CrossRef] 
42. Gautier, E.F.; Leduc, M.; Ladli, M.; Schulz, V.P.; Lefèvre, C.; Boussaid, I.; Fontenay, M.; Lacombe, C.; Verdier, F.; Guillonneau, F.; et al. Comprehensive proteomic analysis of murine terminal erythroid differentiation. Blood Adv. 2020, 4, 1464-1477. [CrossRef] [PubMed]

43. Calzolari, A.; Raggi, C.; Deaglio, S.; Sposi, N.M.; Stafsnes, M.; Fecchi, K.; Parolini, I.; Malavasi, F.; Peschle, C.; Sargiacomo, M.; et al. TfR2 localizes in lipid raft domains and is released in exosomes to activate signal transduction along the MAPK pathway. J. Cell Sci. 2006, 119, 4486-4498. [CrossRef] [PubMed]

44. Sadvakassova, G.; Tiedemann, K.; Steer, K.J.D.; Mikolajewicz, N.; Stavnichuk, M.; In-Kyung Lee, I.; Sabirova, Z.; Schranzhofer, M.; Komarova, S.V. Active hematopoiesis triggers exosomal release of PRDX2 that promotes osteoclast formation. Physiol. Rep. 2021, 9, e14745. [CrossRef] [PubMed] 